DigitALCOMMONS @WAYNESTATE-
Michigan Journal of Counseling: Research, Theory and Practice

Volume 34 | Issue 1

Article 2

$5-1-2007$

\title{
A Statewide Survey of School Counselors' Perceptions on School Issues
}

Elizabeth A. Broughton

Eastern Michigan University

Ronald D. Williamson

Eastern Michigan University

Follow this and additional works at: https://digitalcommons.wayne.edu/mijoc

\section{Recommended Citation}

Broughton, E. A., \& Williamson, R. D. (2007). A Statewide Survey of School Counselors' Perceptions on School Issues, Dimensions of Counseling, 34(1), 1-7. doi:10.22237/mijoc/1177977660

This Article is brought to you for free and open access by the Open Access Journals at DigitalCommons@WayneState. It has been accepted for inclusion in Michigan Journal of Counseling: Research, Theory and Practice by an authorized editor of DigitalCommons@WayneState. 


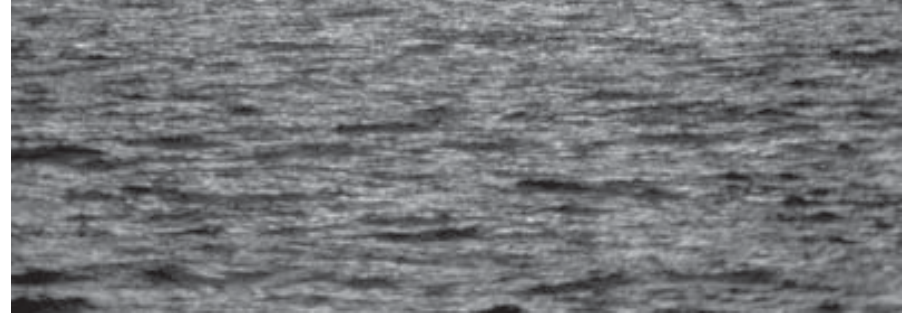

\section{A Statewide Survey of School Counselors' Perceptions on School Issues}

\author{
Elizabeth A. Broughton and Ronald D. \\ Williamson
}

Eastern Michigan University
School counselors maintain a unique professional role in a school setting. This article explores the perceptions of 255 school counselors in the State of Michigan on three contemporary school counseling issues: (a) pre-service training, (b) the professional role of counselors, and (c) school-related issues, related to the professional role of counselors. The results found no differences based on age among school counselors regarding school issues, while gender differences were found on three school issues. The results suggest that on certain issues, school counselors continue to be challenged with role ambiguity.

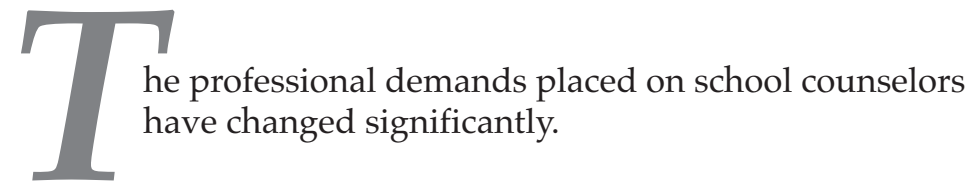

Historically, school counselors focused on the vocational development of students. As academic preparation and professional standards for school counselors increased, the school counselors' professional role changed.

Presently, the role of the school counselor has evolved from basic administrative responsibility to applying a comprehensive guidance plan (Baker, 2001). This comprehensive guidance plan places many demands on school counselors that involve multiple counseling tasks with individuals and groups, as well as applying programming skills, dealing with various stakeholders, and utilizing expertise in school improvement and student achievement initiatives. Because of their unique role in school settings, school counselors are often challenged while attempting to meet these demands. 
These multiple demands contribute to one of the major challenges school counselors confront, which is role definition or ambiguity (Paisley \& McMahon, 2001; Sears \& Granello, 2001). The demands of day-to-day school emergencies many times differ with administrative and / or legislative demands, and these discrepancies can cause school counselors' priorities to shift, For example, the No Child Left Behind Act of 2001, a recent priority, encourages school counselors to assist with the legislation's shift of focus to improving school achievement. This has led, in many cases, to more administrative responsibilities for school counselors, rather than traditional counseling responsibilities.

Another challenge for school counselors is dealing with various stakeholders, particularly with school principals. While sharing a common interest in serving students, school counselors and principals often approach student concerns from different points-of-view, based on varied preparation and philosophical orientation (Kaplan, 1995; Shoffner \& Williamson, 2000). For example, in regards to student discipline, counselors are bound to different ethical codes of confidentiality than are school administrators. These varied perspectives may lead to conflict, and can cause ineffective use of time and energy for both counselors and principals, thus contributing to role ambiguity for school counselors.

This ongoing debate regarding the role of the school counselor continues to confront the school counseling profession (Baker, 2001). The purpose of this study was to examine the perceptions of school counselors on several school issues related to their professional role. This study builds on an earlier project that involved aspiring school counselors and school leaders in a cross-discipline graduate class that examined differing roles, legal, philosophical, and ethical expectations for each group, and approaches to collaboration (Williamson \& Shoffner, 2002). Redefining the role of school counselors in our schools remains a national priority (Baker, 2001; Paisley \& McMahon, 2001). To assist in dealing with this priority, an exploration of several school issues may help school counselors and assist in clarifying the school counselors' role.

\section{Method}

Based on prior research by Shoffner and Williamson (2000), a survey questionnaire was developed to assess school counselors' perceptions on a number of relevant issues regarding their daily work and professional role. The survey was constructed with statements such as, "school counselors should deliver discipline to students," and "school counselors should be certified as teachers." These 24-items were divided into three areas: (a) preservice training, (b) professional role, and (c) schoolrelated issues. Respondents were asked to indicate their agreement or disagreement to the 24 statements, using a 5-point Likert scale of 1 (strongly disagree), 2 (disagree), 3 (neutral), 4 (agree) and 5 (strongly agree). In addition to these 24 content items, demographic information about the participants was collected that included the following variables: gender, age, academic and professional credentials, school location, and years of professional experience.

Both content and face validity were established for the survey prior to pilot testing. Based upon the results of the pilot study, modifications were made to the survey, and the survey items were finalized. The refined questionnaire was also used in a parallel study conducted with school administrators ( $\mathrm{N}=320$; Williamson, Broughton, \& Hobson, 2003).

A sample of 520 school counselors was randomly selected from the Michigan School Counseling Association (MSCA) membership list. Each member of the sample was mailed the following materials: a letter of introduction, the survey questionnaire, and a selfaddressed envelope to return the questionnaire to the research team. Surveys were completed and returned by 290 participants, for an initial response rate of $56 \%$. However, not all members of the MSCA are practicing school counselors. Each returned survey was reviewed to determine if the participant had actually served as a school counselor. Of the original 290 returned surveys, 35 were discarded since it was determined that the participant did not serve as a school counselor. Following this review, a total of 255 surveys were considered useable, for a $49 \%$ usable response rate.

These data were analyzed using both descriptive and inferential statistics. Descriptive statistics were first computed to identify the demographic characteristics of the participants. Then, descriptive statistics including the number, means, and standard deviations for each of the 24 content questions were determined. Finally, chi-square procedures were used to determine if statistically significant differences existed on responses to the 24 questions based on gender and age. The research team selected the demographic variables of gender and age, because it was decided that these two characteristics would have the most impact on the school counselors' perception of their role. Chi-square was used in lieu of a t test because the data were not considered continuous and did not meet other assumptions associated with the test (e.g., homogeneity of variance).

\section{Results}

Of the 255 respondents, $16 \%(n=52)$ were men and $84 \%$ $(n=203)$ women. The majority of the sample was more than 40 years old $(n=190,75 \%)$. Advanced degrees were held by $99 \%$ of the participants. Almost $93 \%(n=236)$ of the school counselors held teaching certificates. Slightly 
over $40 \%(n=103)$ of the participants described their work setting as a rural school, 45\% ( $n=113)$ reported being employed in a suburban school, and $14 \%(n=36)$ indicated working in an urban school. The work setting of less than $1 \%(n=3)$ was not identified.

Considerable K-12 work experience was found among the respondents. The length of service working in K-12 schools ranged from 1 to 48 years of experience. The majority of the sample had more than 10 years of K-12 school experience $(n=187,74 \%)$. The age of the respondents, their credentials, and years of K-12 work experience represented an experienced sample of school counselors.

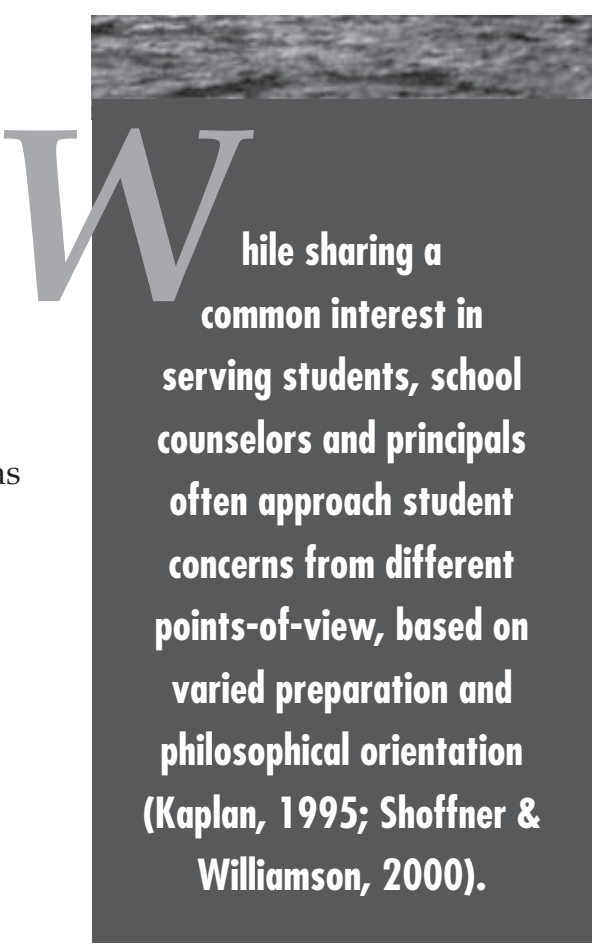

referred to school counselors' perceptions regarding their professional roles in regards to confidentiality issues. School counselors perceived that confidentiality should be maintained regarding student issues $(M=4.31, S D$ $=.94$ ) but also believed that there are situations in which confidentiality should be broken $(M=4.22, S D=.82)$. Chi-square analysis indicated a statistically significant difference in the implementation of a comprehensive guidance system when compared by gender $\left(\mathrm{X}^{2}(1, N=\right.$ $255)=19.19, p<.001$. Women $(M=$ 4.62) were more likely to support a comprehensive guidance system than men $(M=4.19)$.

\section{Pre-Service Training}

Several survey items (1-8) in Table 1 are related to the perceptions of the academic preparation reported by school counselors. This study indicated that school counselors perceived that their academic preparation in counseling skills was strongly developed $(M=4.24, S D=$ $.77)$, and the necessary skills for their job were adequately developed $(M=3.62, S D=1.09)$. Participants indicated that their academic preparation in problem solving $(M=$ $3.73, S D=.95)$, leadership skills $(M=3.34, S D=1.02)$, career development $(M=3.40, S D=1.19)$, and team building $(M=3.38, S D=1.01)$ were adequately developed. School counselors indicated that their academic preparation was not well developed in crosstraining with other professionals $(M=2.81, S D=1.05)$. Finally, school counselors perceived that their academic preparation provided the necessary skills for working collaboratively with faculty and staff $(M=3.09, S D=$ 1.08). Chi-square analysis for each of these items did not establish any statistically significant differences based on the variables of gender and age of the participants.

\section{Professional Role}

Regarding their professional role, school counselors were asked to respond to their perceptions of role responsibilities in schools. School counselors strongly perceived that they worked collaboratively with teachers $(M=4.63, S D=.62)$. They strongly supported implementing K-12 career development programs for students $(M=4.55, S D=.70)$ and a $K-12$ comprehensive school guidance program $(M=4.53, S D=.767)$. School counselors strongly perceived that they worked well with faculty and staff on issues related to career development for students $(M=4.25, S D=.921)$. The next two items

\section{School-Related Issues}

The remaining survey items examined school counselors' perceptions regarding school-related issues such as, career development, collaboration and conflict among school professionals, teaching certification for school counselors, and student discipline. School counselors believed teachers should deliver career development as part of the curriculum $(M=4.10, S D=.85)$. School counselors' felt less strongly about school counselors delivering career development in the classroom $(M=3.86$, $S D=.99$ ). They also perceived less strongly that priorities for school administrators and school counselors often conflicted with each other $(M=3.51, S D=1.19)$. The counselors reported that school counselors worked collaboratively with each other $(M=4.27, S D=.83)$ but were less likely to report that their school involved teachers, administrators, and school counselors in curriculum decisions $(M=3.67, S D=1.16)$. Finally, the counselors indicated strongly that school counselors should be certified as teachers $(M=4.27, S D=1.07)$.

The last four survey items were concerned with the administration of student discipline. The counselors believed strongly that school counselors should not deliver student discipline $(M=1.41, S D=.80)$. Chi-square analysis found a statistically significant difference among respondents based on gender regarding school counselors' involvement with the delivery of discipline to students $\left(X^{2}(1, N=255)=14.68, p<.05\right)$. Men $(M=1.63)$ were more likely to believe that school counselors should be involved in the delivery of discipline to students than women $(M=1.35)$.

Separate from delivery of student discipline, the survey examined whether school counselors should be 
Table 1

Differences of School Counselor Perceptions of Their Role in the School Setting by Gender

\begin{tabular}{lccccc}
\hline & \multicolumn{4}{c}{ Means } \\
\hline & $\begin{array}{c}\text { Men } \\
(n=52)\end{array}$ & $\begin{array}{c}\text { Women } \\
(n=203)\end{array}$ & $\begin{array}{c}\text { Average } \\
(\mathrm{N}=255)\end{array}$ & SD \\
\hline $\begin{array}{l}\text { 1. My pre-service training prepared me } \\
\text { with counseling skills. }\end{array}$ & 4.21 & 4.25 & 4.24 & .77 \\
\hline $\begin{array}{l}\text { 2. My pre-service training provided the } \\
\text { necessary professional skills for my } \\
\text { current position. }\end{array}$ & 3.69 & 3.60 & 3.62 & 1.09 \\
& & & & \\
\hline
\end{tabular}

3. My pre-service training prepared me $\quad \begin{array}{lllll}3.65 & 3.75 & 3.73 & .95\end{array}$ with problem solving skills.

4. My pre-service training prepared me with $\begin{array}{lllll}3.27 & 3.35 & 3.34 & 1.02\end{array}$ leadership skills.

$\begin{array}{llllll}\text { 5. My pre-service training prepared me } & 3.33 & 3.41 & 3.38 & 1.01\end{array}$ with team building skills.

$\begin{array}{llllll}\text { 6. My pre-service training provided } & 3.25 & 3.44 & 3.40 & 1.19\end{array}$ career development training for $\mathrm{K}-12$.

$\begin{array}{llllll}\text { 7. My pre-service training encouraged } & 2.77 & 2.82 & 2.81 & 1.05\end{array}$ cross training with other professional disciplines.

$\begin{array}{llllll}\text { 8. My pre-service training provided me } & 3.10 & 3.09 & 3.09 & 1.08\end{array}$ with collaborative training to work with faculty and staff.

\begin{tabular}{lrrrr}
\hline 9. I work collaboratively with teachers. & 4.50 & 4.66 & 4.63 & .62 \\
\hline $\begin{array}{l}\text { 10. I support implementing K-12 } \\
\text { career development programs for students. }\end{array}$ & 4.52 & 4.55 & 4.55 & .70 \\
\hline $\begin{array}{l}\text { 11. I work with faculty and others on issues } \\
\text { related to career development for students. }\end{array}$ & 4.38 & 4.21 & 4.25 & .92 \\
\hline
\end{tabular}

12. I support the implementation of a K-12 $\quad 4.19 \quad 4.62 \quad 4.53 \quad .77$ comprehensive school guidance program. *

13. I believe confidentiality should be $\quad \begin{array}{lllll}4.48 & 4.26 & 4.31 & .94\end{array}$ applied strictly regarding student issues.

14. I believe there are situations in which $\quad \begin{array}{lllll}4.29 & 4.20 & 4.22 & .82\end{array}$ confidentiality should be broken.

15. Career development should be delivered $\begin{array}{lllll}4.29 & 4.05 & 4.10 & .85\end{array}$ by teachers as part of the curriculum.

16. Career development should be delivered $\begin{array}{llll}3.85 & 3.86 & 3.86 & .99\end{array}$ by school counselors in the classroom.

17. Priorities for school administrators and $\begin{array}{rrrr}3.58 & 3.50 & 3.51 & 1.19\end{array}$ school counselors often conflict with each other.

18. My school administrators and school $\begin{array}{lllll}4.40 & 4.23 & 4.27 & 1.07\end{array}$ counselors work collaboratively with each other.

19. My school involves teachers, administrators, $3.92 \quad 3.61 \quad 3.67 \quad 1.16$ and school counselors in curriculum decisions.

$\begin{array}{lllll}\text { 20. School counselors should be certified } & 4.48 & 4.22 & 4.27 & .83\end{array}$ as teachers.

$\begin{array}{llllll}\text { 21. School counselors should deliver } & & 1.63 & 1.35 & 1.41 & .80\end{array}$ discipline to students. **

$\begin{array}{lllll}\text { 22. School counselors should be involved } & 2.65 & 2.17 & 2.27 & 1.23\end{array}$ in discipline. ${ }^{\star \star \star}$

23. Principals/Assistant Principals are the $\begin{array}{lllll}2.88 & 2.97 & 2.95 & 1.33\end{array}$ only ones who should be involved in discipline.

24. Principals should consult with school $\quad 4.67 \quad 4.43 \quad 4.48 \quad 64$ counselors regarding student issues.

$*\left(X^{2}(1, N=255)=19.19, p<.001\right.$
$\star \star$
$\left.X^{2}(1, N=255)=14.68, p<.05\right)$
$* \star \star\left(X^{2}(1, N=255)=11.92, p<.05\right)$ 
"involved" in student discipline. The response, similar to the previous question, showed that school counselors believed they should not be involved in student discipline $(M=2.27, S D=1.23)$, though less strongly than the earlier question. Chi-square analysis of the responses found a statistically significant difference when comparing gender perceptions regarding school counselors' involvement with discipline $\left(\mathrm{X}^{2}(1, N=255)=\right.$ $11.92, p<.05)$. Men $(M=2.65)$ were more likely to believe that school counselors should be involved with school discipline than women $(M=2.17)$. School counselors were non-committal about whether principals and assistant principals are the only ones that should be involved in student discipline ( $M=$ $2.95, S D=1.33$ ). Finally, school counselors perceived strongly that principals should consult with school counselors regarding school issues $(M=4.48, S D=.64)$.

\section{Discussion}

Perhaps one of most noteworthy findings from this study was the lack of differences based on age among school counselors. The expectation was that age would be a factor in how school counselors perceive their role in the school. This result may suggest that involvement in a professional organization that encourages new training and knowledge contributed to a shared understanding about the role among different generations of school counselors, the possibility to share knowledge through mentoring relationships, or a lack of change in the perception of school counselors' role in the school setting over time. Similarly, few items found a difference based on gender most notably in the area of student discipline. Student discipline may be perceived to contrast substantially from counseling, a helping profession. Gender differences regarding student discipline is worthy of future research.

Pre-service training appears to support the day-to-day work of school counselors. Responses from counselors were uniformly positive with the exception of one important area, cross- training with other professional roles and collaboration with colleagues holding those roles. Williamson \& Shoffner (2002) reported that various professionals in schools, including school counselors, are trained separately and have few opportunities to learn about one another's responsibilities and role perspectives. Recently, researchers have advocated cross- training and collaboration for school professionals in academic preparation programs, particularly for school his result may

suggest that

involvement in a

professional

organization that

encourages new

training and

knowledge

contributed to a

shared

understanding about

the role among different

generations of

school counselors,

the possibility to

share knowledge

through mentoring

relationships, or a

lack of change in the

perception of school

counselors' role in

the school setting

over time. administrators and school counselors (Kaplan, 1995; Ross \& Herrington, 20052006; Williamson and Shoffner). Providing more clarity and understanding of the differing roles of school professionals may contribute to minimizing any role ambiguity among school counselors.

This study found that there is broad agreement among counselors with regards to the importance of their role in career development and supporting a comprehensive school guidance plan. However, the study found lesser agreement around issues of confidentiality, teacher certification for school counselors, collaboration and conflict among school professionals, and school discipline.

School counselors were clear about their responsibility in the area of career development. The results on three survey items were not unexpected, giving the strong importance that career development holds in schools. As one of their professional roles, school counselors have long supported assisting students with navigating the world of work (Coy, 1999). This persistent support for career development contributes to a clear understanding of this professional role.

There was also strong agreement about the importance of implementation of a comprehensive school guidance plan. Supporting a comprehensive guidance system is tied strongly to the school counselors' professional responsibilities (Baker, 2001). Interestingly, the study found that women $(M=4.62)$ supported the comprehensive school guidance system more than men $(M=4.19)$.

A hallmark of the preparation of school counselors is the emphasis on maintaining confidentiality. Confidentiality is an important counseling cornerstone, especially when dealing with minors. The importance of confidentiality is a major ethical, legal, and professional issue that is addressed in academic preparation programs as well as by the American Counseling Association's Code of Ethics and Practice. Glosoff and Pate (2002) stated that as part of an educational community, confidentiality is a complex balancing act between students, parents, and school systems. In this study, school counselors "agreed" with protecting confidentiality $(M=4.31, S D=.94)$. However, there was also strong support that there are situations in 
which confidentiality should be broken $(M=4.22, S D=$ .82). This result supports Glosoff and Pate's notion that school counselors struggle with balancing confidentiality issues. Isaacs and Stone (1999) found similar results in that the breach of confidentiality was more likely with elementary and middle school counselors than high school counselors. The responses to these two questions demonstrate an interesting professional dilemma among school counselors. It is an important area for further research.

A lack of consistent state and national requirements to become a school counselor has contributed to role ambiguity (Sears \& Granello, 2002). Requiring a teaching certificate to become a school counselor varies from stateto-state. For years, the State of Michigan required a teaching certificate for school counselors. In 2001, the State of Michigan changed this requirement, and a teaching certificate is no longer required for school counselors. In this study, school counselors perceived that school counselors should be certified as teachers $(M=$ $4.27, S D=1.07)$. This result indicates that school counselors' perceptions are incongruent with state changes in the teaching certification. This result may also reflect prior professional training including bias regarding school counselors who are not certified teachers, since almost $93 \%$ of the respondents hold a teaching certificate. Because of the recent changes in Michigan with regard to the certification requirement, this was a surprising result.

Also, contributing to role ambiguity were the results that involved school counselors' perceptions regarding collaboration and/or conflict in the school setting with professional staff. Studies have indicated that conflicts regularly emerged among school personnel as they performed their duties (Kaplan, 1995; Shoffner \& Williamson, 2000). Some recent proposals have encouraged school counselors to work collaboratively with school administrators and teachers (Education Trust, 1997; Williamson \& Shoffner, 2002) to reduce conflict and maximize collaboration. Researchers have advocated for a clear understanding of the differing roles and responsibilities (Ross \& Herrington, 2005-2006) and a mechanism for conversation and collaboration centered on high quality services to students (Williamson \& Shoffner, 2002).

Finally, another issue that contributes to role ambiguity is the recurrent contentious school-related issue of student discipline. Several survey items examined school counselors' perceptions about their role in student discipline. The school counselors were reluctant to deal with student discipline and perceived that principals should deliver school discipline. Some writers and researchers believe that there is some discrepancy regarding involvement with school discipline among school counselors (Broughton, 2005; Kaplan, 1995). There are some who advocate that school counselors should be an integral part of the disciplinary process without involvement in the sanctioning aspect (Burgess \& Dedmond, 1994; Kaplan, 1995). Involvement, separate from administration of discipline, is seen as a way that school counselors can support their students especially upon their return to school. It is clear from the results of this study that school counselors have mixed feelings about such involvement. It will be important in subsequent research to explore this important issue in order to reach a deeper and more complete understanding of the differing views on student discipline among school counselors.

Interestingly, gender differences among school counselors on the topic of student discipline emerged from this study. Men $(M=1.63)$ differed with women $(M=1.35)$ in their self-reported preferences for dealing with student discipline. Men $(M=2.65)$ differed from women $(M=$ $2.17)$ in their self-reported preferences with involvement in student discipline. These findings support the need for further research on the school counselors' role in the disciplinary process, particularly examining the impact of gender differences.

\section{Limitations}

The results of this study are important even with limitations that are inherent in survey research. This study used the MSCA membership list as the population frame. However, not all school counselors in the State of Michigan may be members of this professional association.

\section{Summary}

This study raised important implications for the preparation of school counselors and training beyond the school counselors' formal academic work. School counselors believed strongly for career development programs and a comprehensive school guidance system which provided clarity to their professional roles. Other school

issues examined, such as, teaching certification for school counselors, maintaining confidentiality, collaboration and conflict among school professionals, and dealing with student discipline, were found to warrant further research. Until such time when these issues have universal agreement among school counselors, role ambiguity is bound to occur within the school counseling profession.

At a time that school counselors are expected to manage multiple demands, it is important that school counselors build safe and trusting relationships with school 
administrators, and engage in discussions about professional standards that shape the work of school counselors. Having a clear understanding of roles will allow school counselors to focus on their responsibilities for the best interests of their students (Paisley \& McMahon, 2001).

In conclusion, this study supports the earlier research (Ross \& Herrington, 20005-2006; Williamson \& Shoffner, 2002), and demonstrates a continued need to explore school issues among school counselors, and how the school counselors' role, particularly role ambiguity, may affect their work especially with students.

\section{References}

American School Counselor Association. (2003). The ASCA national model: A framework for school counseling programs. Alexandria, VA: Author.

Baker, S.B. (2001). Reflections on forty years in the school counseling profession: Is the glass half full or half empty. Professional School Counseling, 5, 75-83.

Broughton, E. (2005). Minimizing conflict, maximizing collaboration: Principals and school counselors.

The Principals Partnership. Retrieved December 5, 2005, from http:/ / www.principalspartnership.com/feature.html

Burgess, D.G., \& Dedmond, R.M. (1994). Quality leadership and the professional school counselor. Alexandria, VA: American Counseling Association.
Coy, D.R. (1999). The role and training of the school counselor: Background and purpose. NASSP Bulletin, 83, 2-8.

Glosoff, H.L., \& Pate, R.H. (2002). Privacy and confidentiality in school counseling. Professional School Counseling, 6, 20-27.

Isaacs, M.L., \& Stone, C. (1999). School counselors and confidentiality: Factors affecting professional choices. Professional School Counseling, 2, 258-266.

Kaplan, L.S. (1995). Principals versus counselors: Resolving tensions from different practice models. The School Counselor, 42, 261-267.

Paisley, P.O., \& McMahon, G. (2001). School counseling for the $21^{\text {st }}$ century: Challenges and opportunities. Professional School Counseling, 5, 106-115.

Ross, W., \& Herrington, D. (2005-2006). A comparative study of pre-professional counselor/principal perceptions of the role of the counselor in public schools [Electronic version]. National Forum of Educational Administration and Supervision Journal, 23 (4E), 1-15.

Sears, S.J., \& Granello, D.H. (2002). School counseling now and in the future: A reaction. Professional School Counseling, 5, 164-171.

Shoffner, M., \& Williamson, R.D. (2000). Engaging pre-service school counselors and principals in dialogue and collaboration, Counselor Education and Supervision 40, 128-140.

Williamson, R.D., \& Shoffner, M. (2002). Building bridges: Increased trust and understanding between school administrators and school counselors. AASA Professor, 25(3), 29-35.

Williamson, R.D., Broughton, E., \& Hobson, S.A. (2003). Shaping the future: Collaborative opportunities for school administrators and school counselors. Paper presented at the Annual Conference of the National Council of Professors of Educational Administration, Sedona, AZ. (ERIC Document Reproduction Services No.CG032545). 